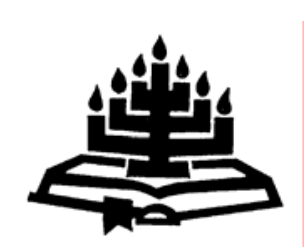

\title{
Christelike gesindheid en ander godsdienste
}

\author{
J.M. Vorster \\ Skool vir Kerkwetenskappe \\ Potchefstroomkampus \\ Noordwes Universiteit \\ POTCHEFSTROOM \\ E-pos: Koos.Vorster@nwu.ac.za
}

\begin{abstract}
Christian attitude and other religions

This article investigates certain models for the practical implementation of religious freedom. The frame of reference is the idea of the kingdom of God, the calling of Christians to care for all people with the attitude of Christ as a leading example and a biblical view on the task of the government. The following models are evaluated: the active theocratic model; the active state religion model; the active universalist model; the active neutralist model and the active pluralist model. The conclusion is that the first four models do not succeed in maintaining peace between religions and can thus be questioned from a Christian ethical point of view. A choice is made for the fifth model, because only an open display of all religions in the public sphere, without restriction and infringings of the state gives religious peace of mind and creates the space for peaceful coexistense. Examples are proposed for the practical application of this model in a constitutional democracy.
\end{abstract}

\section{Opsomming}

\section{Christelike gesindheid en ander godsdienste}

Hierdie artikel ondersoek bepaalde modelle vir die praktiese implementering van die fundamentele reg van godsdiensvryheid in 'n regstaat. Die ondersoek vind plaas binne die raamwerk van die idee van die koninkryk van God, Christene se roeping om volgens die gesindheid van Christus almal se belange te dien en die Bybelse siening oor die taak van die owerheid. Die volgende modelle word aan die orde gestel: die aktiewe teokratiese model, die aktiewe staatsgodsdiensmodel. die aktiewe universalistiese model, die aktiewe neutrale model 
en die aktiewe plurale model. Die konklusie is dat die eerste vier modelle wat hier bespreek word nie daarin slaag om vrede tussen godsdienste te bewerkstellig nie. Sodanige modelle kan dus bevraagteken word vanuit 'n Christelik-etiese perspektief. 'n Keuse word dan gemaak ten gunste van die aktiewe plurale model, omdat slegs die vryheid van elke godsdiens om openlik in die openbare domein te funksioneer, vreedsame naasbestaan tussen mense van verskillende godsdienstige oortuigings kan verseker. Voorbeelde van hoe hierdie model in 'n regstaat kan funksioneer, word verder bespreek.

\section{Inleiding}

Die wyse waarop godsdiensregte in 'n grondwetlike demokrasie beskerm moet word is tans weer onder die soeklig. In resolusie 2004/36 van die Menseregtekomissie van die Verenigde Nasies word godsdiensregte gedefinieer as die reg van elke individu tot vryheid van denke, gewete, godsdiens of geloof, die reg om hulle eie godsdiens vrylik te beoefen of om van oortuiging te verander. Die verpligting lê op die owerheid om grondwetlike en institusionele waarborge daar te stel om hierdie basiese reg te beskerm (VN, 2004:6 en 20).

Herbesinning oor die toepassing en bevordering van hierdie basiese reg het nodig geword vanweë die nuwe konflikte tussen gemeenskappe van verskillende godsdienstige oortuigings wat in verskeie lande voorkom. Die gebeure van 11 September 2001 en die oorloë wat daarop gevolg het, het spanning tussen sommige fundamentalistiese Moslemgemeenskappe en Westerse gemeenskappe verhoog. Sedertdien het godsdiensgeïnspireerde onrus en gewapende verset toegeneem in lande met groeiende godsdiensplurale gemeenskappe soos Frankryk, Duitsland, Spanje, Israel en Australië. Ook in Moslemlande soos Saudi Arabië, Pakistan en Indonesië het vyandigheid teenoor Christene en Christelike kerke toegeneem, terwyl Islamitiese minderheidsgroepe in verskeie ander gemeenskappe aggressie en vyandigheid ervaar het (VN, 2005:11). Die skending van godsdiensregte wissel van openlike geweldpleging tot die verbanning van godsdienstige leesstof, skending van aanbiddingplekke, geforseerde bekerings en godsdienstige verpligtings wat, teen hulle sin, op vroue en kinders van ander gelowe opgelê word. Daar is ook getuienis dat sommige owerhede van godsdienste verwag om te registreer en dan hierdie verpligting gebruik om teen godsdienste te diskrimineer (VN, 2005:17). Hierdie gebeure het die reg van godsdiensvryheid weer op die voorgrond geplaas, veral omdat skending van die vryheid van godsdiens 
dikwels ook lei tot die skending van ander fundamentele regte. $1 \mathrm{Om}$ hierdie rede word daar tans in die menseregtedebat besin oor grondwetlike modelle wat verdraagsaamheid tussen mense van verskillende godsdienstige oortuigings kan verseker en vrede op hierdie terrein kan vestig.

Die doel van hierdie artikel is om verskeie moontlikhede vir die effektiewe toepassing van godsdiensregte vanuit 'n Christelik-etiese hoek te ondersoek. Die volgende vrae word aan die orde gestel: Wat moet die gesindheid van die Christen wees teenoor ander godsdienste en die reg van mense van ander godsdienstige oortuigings om hulle godsdiens ongehinderd te beoefen? Wat behoort van die owerheid in hierdie verband verwag te word?

Hierdie vrae is belangrik om twee redes. Eerstens moet in gedagte gehou word dat die Christelike geloof 'n missionêre godsdiens impliseer. Die verkondiging van die evangelie aan almal - ook aan mense van ander godsdienste - is die hart van die Christelike geloof. Juis hierdie missionêre aard van die Christelike geloof het in die geskiedenis en ook vandag tot groot spanning en konflik met mense van ander godsdienste gelei. Die Christendom is in daardie kringe gesien as 'n dominerende godsdiens wat 'n bedreiging vir die eie godsdienstige identiteit inhou. Daar word ook geoordeel dat die missionêre aard op onaanvaarbare geestelike hoogmoed en Westerse elitisme en selfs arrogansie dui. Die vraag is dus hoe die missionêre aard van die Christelike geloof gehandhaaf kan word in 'n model van godsdiensvryheid, sonder dat dit vir 'n ander godsdiens 'n bedreiging inhou.

Tweedens gee die geskiedenis van die Christelike kerk blyke van ernstige godsdiensvervolging wat in die naam van Christus gepleeg is. In die na-Konstantynse periode is die kerk verpolitiseer en het sendingwerk saamgeval met die grensuitbreidings van koninkryke. Die Corpus Christianum van die Middeleeue het die staat sodanig

1 Die spesiale rapporteur oor vryheid van godsdiens en geloof het voor die Menseregtekomissie van die Verenigde Nasies in 2005 soos volg gerapporteer:

A majority of the cases and situations that had been brought to the attention of the Special Rapporteur and that reveal a violation of the right to freedom of religion or belief also involve violations of other human rights, including violations of the right to life, the right not to be subjected to torture, cruel inhuman or degrading treatment or punishment, the right to liberty and security of person, the right to freedom of movement, residence, nationality, peaceful assembly and association, and the right to freedom of opinion or expression (VN, 2005:14). 
verpolitiseer dat die wil van die Pous op almal afgeforseer is en dat vrye keuse in godsdiensbeoefening onmoontlik was. Die daaropvolgende kruistogte het 'n donker periode ingelui van geweldpleging teenoor die Islam onder die banier van die koninkryk van God. Hierby kan gewys word op die bloedige "sendingwerk" van die Rooms-Katolieke kerk in Latyns-Amerika, die godsdiensoorloë in Europa tussen Rooms-Katolieke en Protestante en die wrede vervolging van die Anabaptiste deur albei. Die historiese voorbeelde van die negatiwiteit en selfs vervolgsugtigheid van Christene se optrede teenoor mense van ander godsdiensoortuigings, laat die vraag ontstaan of die Christelike geloof in staat is om godsdiensvryheid te respekteer en hoe die Christelike geloof hierdie diepliggende wantroue kan afskud. Daarom is dit noodsaaklik om die konsep van godsdiensvryheid verder te ondersoek vanuit die perspektief van die Christelike etiek.

Hierdie ondersoek begin met die uiteensetting van Bybelse perspektiewe wat vir die saak van godsdiensregte van belang is. Daarna word verskillende opsies vir die toepassing van godsdiensregte aan die orde gestel en eties beoordeel.

\section{Bybelse perspektiewe}

In die Bybelse openbaring is die volgende temas belangrik wanneer godsdiensregte vanuit die perspektief van 'n Christelike gesindheid ondersoek word:

- die idee van die teokrasie in die Ou en Nuwe Testament;

- die opdragte wat gegee word aan gelowiges ten opsigte van hulle gedrag teenoor alle mense; en

- die gegewens oor die roeping van die owerheid.

- Hieraan word vervolgens aandag gegee.

\subsection{Die teokrasie in die Ou Testament}

Die gedagte van die teokrasie in die Ou Testament hang ten nouste saam met die openbaring oor die koninkryk van God en die betekenis daarvan vir die volk van God in die Ou Testament. Om die teokrasie te bespreek, moet eers aandag gegee word aan die koninkryk van God in die Ou Testament.

In die Ou Testament is die begrip koninkryk van God 'n sentrale motief, al word die uitdrukking as sodanig nie daarin aangetref nie. Beasley-Murray (1987:17) wys tereg daarop dat die eksegeet nie 
net 'n suiwer linguistiese benadering moet volg nie, maar moet soek na die dieperliggende saak. Hoewel die uitdrukking "koninkryk van God" nie voorkom nie, openbaar die Ou Testament God as die accompanying God wat in 'n lewende verhouding sy volk as Koning regeer. Vriezen (1966:93) beskou ook die vestiging van God se koningskap op aarde en sy ryk onder mense, as die doel van God se openbaring in die Ou Testament. Volgens Du Toit (1969:11) is dit juis die koninkryksgedagte wat die Ou en Nuwe Testament met mekaar verbind en aan die twee Testamente hulle eenheid verleen.

Wat leer die Ou Testament oor die koninkryk? Helberg (1980:4) vat die hele saak, soos dit deur die Ou-Testamentiese openbaring ontvou word, in die volgende konklusie saam:

God heers heilig en lewewekkend oor alle dinge en Hy beoefen persoonlike gemeenskap, en wel verbondsgemeenskap, met die mens. God doen dit ondanks die dodelike gevallenheid van die mens in die wêreld. Dit geskied deur God se openbaring in sy Woord en die geskiedenis (insluitende die skepping of natuur). Die koninkryk hou in dat God vir Hom 'n volk tot stand bring wat deel in sy versoenende genade, wat glo in sy lewewekkende mag, wat diep afhanklik van Hom voel, wat leef in dankbaarheid en in roepingsbewustheid teenoor God en die naaste en teenoor God se skepping en wat in hierdie wêreld op God hoop.

In die gedagte van die koninkryk van God in die Ou Testament, gaan dit dus om God wat heers en daardeur uit 'n gevalle wêreld 'n lewende verbondsgemeenskap tot stand bring, wat met Hom in 'n persoonlike verhouding leef. Beasley-Murray (1987:20) beklemtoon teen hierdie agtergrond die universaliteit van God se regering (bv. in Jes. 26:1-15; $28: 5$ e.v.; 33:5 e.v.; Eseg. 11:17 e.v.; 20:33 e.v.; Hos. 2:16-17 en Sag. 8:1-8), die geregtigheid van die koninkryk (bv. in Jes. 11:3-5; Jer. 23:5-6; 28:5-6; Eseg. 36:25-26; 37:23-24) en die vrede van die koninkryk (bv. in Jes. 2:2-3; Miga 5:4; Sag. 9:9-10; Hos. 2:21-22 en Sef. 3:14-20). God se regering en sy gemeenskap met mense lok reaksie uit. Mense kom tot geloof, vorm 'n nuwe verbondsgemeenskap en beoefen liefde en trou teenoor God en hulle naaste.

Hierdie koningskap van God word gerealiseer in die lewe van die volk. Maar dan moet in gedagte gehou word dat dit gaan om die lewe binne "staatsverband", omdat die volk as verbondsgemeenskap en die volk as staatkundige entiteit saamgeval het. Die volk in religieuse $\sin$ is dieselfde as die volk in staatkundige sin en hulle mag geen afgode aanbid of enige vorm van afgodery toegelaat het 
nie. Die Here het Hom vertoorn oor afgodery (Jos. 23). Binne die ou Israelitiese staatsgemeenskap is geen "godsdiensvryheid" toegelaat nie. Die godsvolk moes die Here alleen dien. Tog is mense van ander godsdienstige oortuiginge nie uitgeroei nie. Inteendeel, die Here vereis geregtigheid teenoor die "vreemdelinge". Israel het in sy eie kring geen godsdiensvryheid geken nie, maar ander godsdienste het wel in ander staatkundige verbande gefigureer en vreedsaam met die godsvolk saambestaan.

\subsection{Die teokrasie in die Nuwe Testament}

Dieselfde grondgedagte word in die Nuwe Testament aangaande die begrip koninkryk van God aangetref. Die Nuwe Testament omskryf die saak met verskeie uitdrukkings soos die koninkryk van die Hemele (bv. Matt. 3:2; 4:17; 11:12; 16:19, ensovoorts); koninkryk van God (bv. Mark. 1:14; 9:47; 10:24; Luk. 6:20; Hand. 1:3; Rom.14:17; 1 Kor. 4:20; Kol. 4:11); koninkryk van God en van Christus (Ef. 5:5), Koninkryk (Matt. 4:23; 9:35 en 13:19) en koninkryk van die Vader (Matt. 13:43; 26:29).

Schmidt (1969a:582) toon aan dat al hierdie begrippe dieselfde kernbetekenis het. 'n Ontleding van die begrippe binne hulle eie konteks bewys dat die koninkryk 'n omvattende gesigspunt verteenwoordig wat nie maklik onder een noemer gebring of in 'n bepaalde skema ingedruk kan word nie. Van der Walt (1962:32) waarsku teen so 'n vereensydiging en gee op grond van deeglike eksegetiese en openbaringshistoriese getuienis die volgende samevatting oor die koninkryk in die Nuwe Testament:

Die koninkryk is iets wat kom (Matt. 6:10; par. Luk. 11:2, ensovoorts), en wel tot mense (Matt. 12:28 par.) - maar dit is ook iets waartoe mense kom en ingaan (Matt. 5:20; 7:21; 18:3; Mark. 9:47 ens.) en terselfdertyd ook 'n plek of 'n 'sfeer' (Matt. 5:19; 8:11; Luk. 13:28 ens.).

In die koninkryk is die heilryke soewereiniteit van God altyd teenwoordig: eerstens as daad, tweedens as terrein en derdens wat in die almagsuitoefening gebeur (Van der Walt, 1962:33).

Die grondlyne wat die Ou Testament oor die koninkryk bied, word in die Nuwe Testament voortgesit. Die hele openbaring van God in sy Woord ontvou die koninkryk van God dus as die daadkragtige deurlopende regering van God. Hierdeur kom mense tot geloof en hulle staan in 'n nuwe verhouding tot God en tot mekaar. Deur die krag van die Gees werk hulle vernuwend in op die wêreld deur vrede, versoening, hoop en liefde te verkondig, te beoefen en te 
vergestalt. Maar watter perspektief bied hierdie insigte vir godsdiensvryheid in 'n moderne konteks?

Die Nuwe Testament verkondig die koningskap van Christus oor alle dinge (Matt. 28:18; Kol. 1:15-20; Küng, 1992:47). Hierdie koningskap is 'n teenswoordige en ook in toekomende realiteit (Conzelmann, 1976:114). As toekomstige realiteit vestig die koninkryk van God en van Christus die volkome bedeling wat deur die Wederkoms van Christus werklikheid sal word. Dan sal die gelowiges saam met Christus oor alles regeer. Maar dit is ook 'n teenswoordige realiteit en word sigbaar oral waar die knie voor Christus gebuig word. Die duidelikste teenswoordige teken van die koninkryk is die kerk en die getuienis en lewe van die gelowiges. Die Nuwe-Testamentiese teokrasie wat in die koninkryk van God gestalte kry, impliseer egter nie slegs 'n politieke entiteit nie. Die Koninkryk het implikasies vir die politiek, maar word nie as 'n politieke dispensasie gerealiseer nie. Hiermee word die lyn van die $\mathrm{Ou}$ Testament gediskontinueer. Anders as in die Ou Testament, is die Koninkryk 'n geestelike gesagsfeer wat die kerk en die gelowiges raak en wat gesoek word deur die prediking van die Woord en die gehoorsaamheid daaraan. Waar die beoefening van ander godsdienste in die Ou Testament in die Israelse "staat" verbied is, word dit in die Nuwe Testament in die kerk verbied.

Nêrens in die Nuwe Testament word van die owerheid verwag om die Christelike geloof met die swaard te vestig en te verdedig nie (Vorster, 2004:218). Daar word ook nie van die staat verwag om ander gelowe te vervolg nie. Trouens Christus erken die bevoegdheid en die gesag van die Romeinse keiser en sowel Paulus as Petrus verwag van die gelowige om aan die owerheid gehoorsaam te wees en vir die owerheid voorbidding te doen - ook vir die nieChristelike owerheid.

Uit die ontwikkeling van die konsep van die teokrasie in die Godsopenbaring kan die volgende etiese beginsel ten opsigte van godsdiensvryheid afgelei word: Die gelowige mag nie ander gode dien nie en afgodery mag nie in die kerk toegelaat word nie. Hierdie beginsel word egter nie in die Nuwe-Testamentiese bedeling op die staat afgedwing nie. Die staat het 'n ander funksie. Hoe moet die gelowige dan optree teen ander gelowiges in staatsverband? Om 'n antwoord hierop te vind, moet op ander Skriftuurlike gegewens gelet word. 


\subsection{Die gelowige se pligte teenoor "alle mense"}

Dwarsdeur die Skrif word gelowiges vermaan om nie van die Here te vervreem of ander te laat vervreem nie. Die dien van ander gode of die navolg van vreemde leerstellinge en 'n onchristelike lewenswandel word sterk afgewys. Gelowiges word gewaarsku teen dwaalleer (2 Pet. 2:1-22; Jud. 1) en moet in leer en lewe die Here alleen dien. Daarmee saam moet gelowiges altyd bereid wees om dissipels van al die nasies te maak (Matt. 28:19-20) en om teenoor almal te getuig oor "die hoop wat in hulle is" (1 Pet. 3:15).

Tog beteken hierdie gebondenheid aan die Here en die gehoorsaamheid aan sy wil nie dat mense van ander oortuigings vervolg, onderdruk of verneder moet word nie. Die Christelike gesindheid van liefde, diens, self-oorgawe aan ander en gehoorsaamheid aan God moet ook in die behandeling van mense buite die kring van die gelowiges na vore kom. Die liefde wat van gelowiges verwag word, moet deurdring na alle mense binne alle samelewingsverbande. Die volgende Skrifgedeeltes gee blyke van hierdie inklusiewe liefde:

- Matteus 5:43-48: "Julle moet julle vyande liefhê."

- Lukas 6:31: "Behandel ander mense soos julle self behandel wil word."

- 1 Tessalonisense 5:15: “... beywer julle eerder vir die belange van alle medegelowiges en van alle mense".

- Galasiërs 6:9: "Laat ons dan nie moeg word om goed te doen nie ... Solank ons die geleentheid het moet ons aan almal goed doen, maar eers aan die huisgenote van die geloof."

Fedler (2006:176) omskryf die reikwydte van die Christelike liefde in navolging van Christus en as uitbeelding van die gesindheid van Christus as liefde, kruisdra, opoffering en diens. Dit is die aard van die gelowige se bestaan in die wêreld. Die Christelike liefde is universeel want:

Jesus demonstrates love not just for his family and friends, and not just for the powerful, beautiful, or righteous, but for the sinner, the outcast, and the stranger. Jesus' love knows no borders, and like the Father who sent him, Jesus had a special concern for those people who too often fall outside the scope of most people's love and concern (Fedler, 2006:180). 
Die gelowige moet dus na die belange van alle mense omsien en selfs hulle belange bevorder. Om godsdiens vryelik te bely, te beoefen en uit te dra is een van die belangrikste fundamentele regte, want dit raak die mens se diepste gevoelens en oortuigings. Wanneer hierdie reg geskend word, gryp dit die mens in sy wese aan. Liefde tot alle mense, diens en opoffering as die kernelemente van 'n Christelike gesindheid noop die Christen om die godsdiensvryheid van alle mense te bevorder. Dit beteken nie dat die evangelie nie aan ander verkondig mag word nie. Die uitdra van die evangelie is deel van die Christen se eie godsdiensregte, maar dit word gedoen deur die kerk en nie deur die swaardmag van die owerheid, soos dikwels met groot negatiewe gevolge in die verlede gedoen is nie. Evangelisering moet ook in die gesindheid van liefde geskied en moet gepaard gaan met die Christelike roeping om goed te doen aan alle mense. Veroordelende arrogansie tas die essensie van Christelike gesindheid aan.

Die roeping van Christene om toe te sien dat ander mense se godsdiensregte beskerm moet word, word goed verwoord in die Testimony on Human Rights van die Gereformeerde Ekumeniese Raad (1983:151). Hierdie dokument sê oor die taak van Christene om godsdiensregte te realiseer, die volgende:

The right to freedom and worship - challenging us to intervene on behalf of persecuted worshiping communities, Christians and others, assuring them of the opportunity to gather in their places of worship without molestation, discrimination or reprisal; the rights to religious liberty - challenging us in a religious pluralist world to plead the cause of all persons and communities to freely choose and change their religions, to live out their beliefs freely, both privately and publicly, within the various structures of society, without infringing on the rights upon the similar rights of others ...

Hierdie afdeling oor Bybelse perspektiewe ten opsigte van Christelike gesindheid teenoor ander godsdienste word afgesluit met 'n kort omskrywing van die gereformeerde visie op die roeping van die owerheid.

\subsection{Die roeping van die owerheid}

Volgens Romeine13:1 kom alle gesag van God af en dit sluit ook die gesag in wat in staatsverband beoefen word (Douma, 1996:179). God het die owerheid ingestel as gevolg van die realiteit van die sonde. Aan die owerheid word gesag toegeken om te regeer: "sodat ons 'n rustige en stil lewe kan lei in volkome toewyding aan God en 
in alle eerbaarheid" (1 Tim. 2:2). Die gelowiges word opgeroep om vir die owerheid voorbidding te doen, sodat hierdie taak getrou uitgevoer kan word. In Romeine 13:3 word gestel dat die owerheid die reg het om te straf en dat owerhede regeer tot die beswil van mense.

Binne die raamwerk van hierdie prinsipiële gegewens kan die volgende norme neergelê word vir die owerheid se roeping ten opsigte van godsdiensvryheid:

- Die owerheid moet aan God verantwoordelik wees. In konkrete terme beteken hierdie verantwoordelikheid om so te regeer dat die beginsels van die Koninkryk tot vergestalting kan kom. Dit geld ook die sogenaamde sekulêre of neutrale owerheid. Hierdie beginsels raak sake soos die bevordering van vryheid, menswaardigheid en gelykheid en algemene lewensmoraliteit. Vryheid impliseer vryheid van oortuiging, denke, uitdra van standpunte en godsdiens. Wanneer die owerheid godsdiensbeoefening beperk, word vryheid misken. Menswaardigheid beteken om die mens toe te laat om mens te wees en impliseer die reg om sy diepste emosies, soos in godsdiens vervat, uit te druk. Gelykheid impliseer gelyke behandeling van alle godsdienste voor die reg.

- Die owerheid moet orde handhaaf. Onderdane moet beskerm word teen diegene wat wet en orde ondermyn en teen aggressie en uitbuiting van ander in die gemeenskap.

- Die owerheid moet reg en geregtigheid dien. Alle mense moet billik en regverdig behandel word. Almal moet gelyk wees voor die reg en effektief kan deelneem aan die vestiging en verandering van die staat (Rawls, 2001:392). Almal moet ook die reg hê om in enige owerheidsamp te dien. Daarom mag die owerheid teen niemand diskrimineer nie. Geregtigheid impliseer dus die erkenning van godsdiensregte en die gelyke behandeling van alle godsdienste.

- Die owerheid moet ruimte skep vir onderdane om te ontwikkel, sowel in materiële as geestelike sin. Onderdane moet in staat wees om hulle talente te ontgin en toe te pas, welvarend te word en die vrug van hulle arbeid op 'n verantwoordelike wyse binne die raamwerk van die wet te geniet.

- Die owerheid moet die vrede bewaar. Waar konflik tussen mense van verskillende godsdienstige oortuigings ontstaan moet die owerheid 'n klimaat en ruimte skep vir godsdienste om vreedsaam naas mekaar te funksioneer. Wanneer owerhede hulle plig 
tot die bewaring van vrede versaak, deur byvoorbeeld die onderdrukking van godsdienste, verloën hulle 'n fundamentele taak.

\section{Etiese perspektiewe}

In haar onlangse beoordeling van opsies vir die implementering van godsdiensregte, onderskei Warnink (2005:1) tussen die aktiewe neutrale opsie en die aktiewe plurale opsie in die implementering van die fundamentele reg van godsdiensvryheid. Verdere nadenke hieroor open, myns insiens, die deur vir die identifisering van nog drie opsies wat in die menseregtedebatte funksioneer. Hierdie drie opsies kan genoem word: die aktiewe staatsgodsdiensopsie, die aktiewe universalistiese opsie en die aktiewe teokratiese opsie. Die genoemde vyf opsies word vervolgens bespreek en daar word gefokus op die betekenis van elkeen, voorbeelde daarvan, die werking daarvan in 'n regstaat en 'n kritiese evaluering van elkeen. $\mathrm{Na}$ hierdie beoordeling word 'n eie keuse gemaak.

\subsection{Die aktiewe teokratiese opsie}

Onder die benaming aktiewe teokratiese opsie word verstaan 'n politieke entiteit wat op die basis van 'n teokratiese samelewingsbeskouing gedefinieer word. In die praktyk beteken hierdie opsie dat 'n bepaalde godsdiens die owerheid van 'n land beheer en dat die hele samelewing ingerig word volgens die beginsels en norme van daardie spesifieke godsdiens. Ander godsdienste word dan óf onwettig verklaar óf hoogstens geduld solank dit nie met die heersende godsdiens in botsing is nie. Voorbeelde hiervan in die geskiedenis is legio. Die groot klassieke voorbeeld in die geskiedenis was die Romeinse Ryk se keiserkultus. Die keiser is as 'n godeseun vereer en almal moes hom as sodanig eer. Daarom is Christene in die eerste eeue na Christus vervolg, omdat hulle 'n ander God wou dien. Die Christendom het egter self ook hierdie opsie later toegepas. In die Middeleeue is die idee van 'n Corpus Christianum, wat deur die Pous beheer is, toegepas. Hierdie uitdrukking het gewys op wêreldwye politieke entiteit in destydse terme. Geen ander godsdienste is toegelaat om te funksioneer nie. Selfs Christelike bewegings soos die Karthare en die Waldense is verbied (Walker, 1992:306 en Green, 1998:95). Hierdie opsie het tot baie bloedvergieting gelei en was deels verantwoordelik vir die godsdienskonflikte tydens die kruistogte.

Díe idee het voortgeleef by sowel die Anabaptiste as die Reformasie. Die Anabaptiste wou met geweld die koninkryk van 
God op aarde vestig (Bonhoeffer, 1995:305). Calvyn het die stadstaat, Genève, ingerig as 'n teokrasie waarin alle ander godsdienste asook afwykings van die gereformeerde leer verbied is (Vorster, 1993:307; Witte, 1996:106; Tierney, 1996:46). Die teokratiese opsie is in die verlede ook in Moslemstate toegepas waar die staat ingerig is volgens die Shari'a, dit wil sê, Islamreg wat deur die eeue ontwikkel is (Blei, 2002:31). Hierdie opsie herleef tans weer in verskeie Moslemlande en is verantwoordelik vir baie godsdienskonflikte en verder vir die skending van ander regte, soos dié van vroue en vreemdelinge. In sommige van hierdie lande is dit voorgeskryf dat die staatshoof 'n Moslem moet wees (Hashmi, 2006:1). Hierdie voorskrif is 'n verdere bewys van die implikasies van die aktiewe teokratiese opsie. 'n Ander voorbeeld van die aktiewe teokratiese opsie was die Japannese grondwet vóór die Tweede Wêreldoorlog. Die eerste artikel van hierdie konstitusie het voorgeskryf dat die bevolking die goddelike oorsprong van die keiser uit die songod moet erken en die keiser as sodanig moet gehoorsaam (Bonhoeffer, 1995:89).

Vanweë die feit dat hierdie opsie geen vryheid van godsdiens, spraak en gewete toelaat nie, het dit in die verlede tot baie vervolging, bloedvergieting en geweld gelei (Vorster, 2004:205). Die godsdiensoorloë van die tydperk ná die Reformasie is 'n goeie voorbeeld hiervan. Dit is opmerklik dat godsdiensvervolging tans veral voorkom in die lande waar die teokratiese opsie aktief beoefen word (VN, 2005:11).

Hoewel die teokratiese opsie in die gereformeerde denke lank by wyse van belydenisskrifte gepropageer is, moet die prinsipiële begronding daarvan bevraagteken word. ${ }^{2}$ Die volgende kritiese opmerkings kan hieroor gemaak word:

- Die gereformeerde tradisie van die teokrasie maak van die koninkryk van God de facto 'n immanente politieke entiteit soos Israel in die Ou Testament. Geen grond daarvoor kan egter in die Skrif gevind word nie. Die toepassing van dié opsie in hierdie tradisie devalueer ook die evangelieverkondiging deur kerke, omdat die samelewing deur sogenaamde Christelike wetgewing van buite gerig word en nie meer van binne deur die invloed van die evangelie op die oortuigings van mense nie. Met ander

2 Belydenisskrifte is intussen in feitlik al die hoofstroomkerke van die gereformeerde tradisie sodanig gewysig dat die teokratiese opsie, soos hierbo bespreek. nie meer daaruit afgelei kan word nie (vgl. Vorster, 1993:307). 
woorde, daar word gepoog om mense se morele waardes deur wette te vorm en nie primêr deur innerlike oortuiging nie. So word 'n Christendomlike samelewing geskep wat nie noodwendig as 'n Christelike samelewing getipeer kan word nie. ${ }^{3}$ lets hiervan het geleef in Suid-Afrika in die apartheidsbedeling. Die owerheid het byvoorbeeld Christelike onderwys voorgeskryf, deur sensuur Christelike sedelike norme beskerm en nie toegelaat dat ander godsdienste van die staatsbeheerde media gebruik maak nie. Sulke wetgewing het die skyn van Christelikheid, maar bevorder eintlik nie die koninkryk van God nie. Die Koninkryk word immers sigbaar waar mense die koningskap van Christus in hulle lewe erken en die beginsels van die Koninkryk uit innerlike oortuiging bely en uitleef. Wette maak nie Christene nie - die evangelie wel.

- Die "aan ander"-deel van die Christen se roeping kom nie in die aktiewe toepassing van hierdie opsie tot sy reg nie. Godsdiens is 'n diep emosionele saak wat die gevoelens en waardigheid van mense ten diepste raak. Wanneer mense godsdienstig geïnhibeer word, wek dit aggressie en pyn. Naasteliefde van die Christen moet hierdie diepste gevoelens van ander in ag neem. Die beoefening van naasteliefde in hierdie verband is nie moontlik in die teokratiese opsie nie. Christene behoort almal toe te laat om hulle godsdiensoortuigings uit te leef, terwyl hulle die evangelie op ' $n$ waardige wyse aan almal verkondig. Die teokratiese opsie ontneem die owerheid van sy godgegewe roeping om orde en vrede te handhaaf en so te regeer dat mense menswaardig kan leef. Deur ander godsdienste in te perk, word ruimte geskep vir onreg, aggressie en geweld soos wat die geskiedenis terdeë getuig. Sodoende word die owerheid, wat vredemaker moet wees, die aggressor.

\subsection{Die aktiewe staatsgodsdiensopsie}

Nóú verwant aan die aktiewe teokratiese opsie, maar tog verskillend, is die aktiewe staatsgodsdiensmodel. In hierdie opsie kies die owerheid van die dag kant vir 'n bepaalde godsdiens en bevoordeel die belange van daardie godsdiens bo dié van ander. Die verskil met die aktiewe teokratiese opsie lê daarin dat hierdie

3 Die term Christendomlike samelewing dui hier op 'n samelewing wat breedweg Christelike norme uitleef en Christelike feesdae handhaaf, maar wat nie noodwendig 'n samelewing is van oortuigde Christene nie. 'n Christelike samelewing is ' $n$ samelewing van mense wat uit innerlike oortuiging bepaalde Christelike beginsels en norme handhaaf. 
model wel ander godsdienste erken en beskerm en nie 'n religieuse teks gebruik as prinsipiële basis vir regering nie. Alhoewel die owerheid in hierdie gevalle nie die staatsregering baseer op die etiese beginsels en norme van die bevoorregte godsdiens nie, word godsdiensvryheid in die sin van die gelyke blootstelling van godsdienste egter daardeur in die wiele gery.

Hierdie modelle het veral in die Europese nasie-state bestaan. Die Verenigde Koninkryk was 'n goeie voorbeeld. "God, King and Country", was die slagspreuk in buitelandse politiek. Hoewel die opsie nie meer de jure bestaan nie, is dit tog de facto nog steeds die posisie. Die koningin is immers steeds die hoof van die Anglikaanse Kerk. Dié opsie spreek ook duidelik uit die sinsnede "God save the Queen" van die nasionale lied.

Ook oor hierdie opsie kan enkele kritiese opmerkings gemaak word:

- Soos in die aktiewe teokratiese opsie, word norme en simbole van een godsdiens op mense van ander oortuigings afgedwing. Is dit werklik 'n uitdrukking van vryheid van gewete as kinders van ander oortuigings en godsdienste "God save the Queen" sing? Vanuit die teologie van godsdienste kan geredeneer word dat elkeen in hierdie lied sy eie godsbeeld kan lees (Vorster, 1994:249). Tog is so 'n opvatting nie korrek nie. Die ontstaan en historiese verloop van uitdrukkings dui duidelik aan dat dit hier gaan om die Christelike Godsbeskouing.

- Agnostici en minderheidsgodsdienste beleef hierdie opsie in die Verenigde Koninkryk as uitsluitend en dus diskriminerend. Die "aan ander"-opdragte in die Skrif noop Christene om hierdie belewenis van uitsluiting ernstig op te neem. 'n Sisteem waarin mense se vryheid van gewete en oortuiging nie voluit gerespekteer word nie, is dus eties nie aanvaarbaar nie. Bowendien word die Christelike godsdiens hierdeur verkeerdelik voorgehou as ' $n$ politieke entiteit en dit bots met die dinamiese karakter van die Koninkryk as 'n groeiende werklikheid in die lewe van mense en wat gerig is op innerlike oortuiging en vergestalt word in die lewe en getuienis van mense. Om van die Koninkryk seremoniële deïsme te maak, verduister die konkrete realiteit van die Christusregering oor alle dinge.

- Hierdie opsie voldoen ook nie aan die vereistes wat die Skrif stel vir die owerheid van die dag nie. Die owerheid moet geregtigheid beoefen en vrede bewaar. Om mense se gewetensvryheid te inhibeer, al is dit slegs met simboliek, is nie geregtigheid in die 
volle sin van die woord nie. In die Ou Testament is selfs van die teokratiese regering van die volk van God verwag om die vreemdelinge, dit wil sê, die mense wat ander gode gedien het, se regte te beskerm (De Vaux, 1988:930; Vorster, 2004:232). Voorts bedreig hierdie opsie die vrede, soos getuig word deur die openbare protes wat godsdienstige minderhede onlangs in die Verenigde Koninkryk en Australië aangeteken het.

\subsection{Die aktiewe neutrale opsie}

Die neutrale opsie funksioneer tans in baie grondwetlike demokrasieë en die bekendste daarvan is die VSA en Frankryk. Volgens hierdie model word kerk en staat totaal geskei. Vryheid van godsdiens word uit die openbare sfeer verskuif na die private domein. Die owerheid maak geen godsdienstige of ideologiese keuse nie en waarborg die vryheid van alle godsdienste, wat voldoen aan die norme van die grondwet, die norme van algemene orde en vrede in die samelewing, om vryelik te funksioneer. Die owerheid beskerm godsdienste teen diskriminasie binne die perke wat die wet stel. ${ }^{4}$ Hierdie opsie het sy ontstaan in die VSA en is gegrond op die sogenaamde "free exercise clause" teenoor die "establishment clause" wat die grondslag van 'n aktiewe staatsgodsdiensopsie is (vgl. Blei, 2002:112; Chaskalson, 1997:100 en Vorster, 2004:209).

Die Amerikaanse Eed van Getrouheid bevat nog steeds die uitdrukking: "One nation under God" en die wenslikheid om dit te behou word tans wyd in die VSA tussen regslui en etici gedebatteer (Kao, 2006:1). Op die geldeenhede van die VSA verskyn ook die uitdrukking: "In God we trust". In regskringe word hierdie uitdrukkings nie gesien as 'n beweging weg van die neutrale opsie

Die beperking geld wanneer godsdienstige handelinge strydig is met die wet. 'n Voorbeeld hiervan is die uitspraak van die konstitusionele hof in Suid-Afrika dat Rastafariërs nie die reg het om mariuana te gebruik as deel van hulle godsdienstige rituele nie, omdat die gebruik van dié middel strydig is met die wet wat die gebruik van skadelike dwelmmiddels beheer. So sal mense wat passifiste is op grond van godsdienstige redes, soos byvoorbeeld die Jehovagetuies, nie noodwendig militêre diens kan weier omdat dit in stryd is met hulle geloofsoortuigings nie. Die owerheid kan oordeel dat sulke diensweiering nie in die belang van die land is nie en die weiering van diens nie as 'n godsdiensreg beskou nie. Jehovagetuies sal dan nie kan aanspraak maak op godsdiensvryheid om militêre diens te vermy nie. So ook kan godsdienste wat poligamie toelaat nie noodwendig met 'n beroep op godsdiensvryheid poligamie beoefen indien die wet 'n huwelik definieër as 'n monogame heteroseksuele verbintenis nie. Neutraliteit het dus perke. 
nie, maar as "seremoniële deïsme" (Kao, 2006:6). Hiermee word bedoel dat die uitdrukkings nie meer 'n betekenisvolle kontemporêre, religieuse betekenis het nie en dat dit geen invloed op die interpretasie van die grondwet het nie (Van der Vyver, 1999:651). Die verwysing na God is eintlik net 'n simbool van die geskiedenis van die nasie.

Die mees ekstreme toepassing van die neutrale opsie vind uitdrukking in die Franse wet (Wet nr. 2004-228 van 15 Maart 2004) waarin skoolkinders verbied word om enige godsdienstige simbole te dra. Christene mag nie hangertjies met die kruis dra nie en Moslemkinders mag nie die sluier (hijab) dra nie. Hierdie wet het teen die einde van 2005 tot onluste in stede in Frankryk gelei, omdat veral Moslems van oordeel was dat daar onder die vaandel van neutraliteit teen hulle gediskrimineer word.

Die volgende kritiese opmerkings kan oor hierdie opsie gemaak word:

- Seremoniële deïsme bevredig geen godsdiens nie, want die degradering van verwysings na God of ander godsbeelde tot seremoniële deïsme is lasterlik in waarskynlik alle teïstiese godsdienste (Van der Vyver, 1999:651). Daarom bevat hierdie opsie die moontlikheid van konflik.

- Die Moslems se ervaring in Frankryk lê 'n ander bepaalde probleem bloot, naamlik die vraag of neutraliteit werklik moontlik is. Kan 'n owerheid ideologies neutraal wees? Word 'n grondwet en wetgewing nie tog maar ook geskryf vanuit 'n bepaalde lewensbeskoulike paradigma nie? Myns insiens is lewensbeskoulike neutraliteit nie moontlik nie. Wat Kuhn (1970:VII) en baie wetenskaplikes na hom oor die paradigmagedrewenheid van die wetenskap sê, is ook op die staatshuishouding van toepassing. Capetz (2004:180) sê, met 'n beroep op Barth, dat humanisme, waarin neutraliteit immers gegrond is, 'n sekulêre surrogaat van godsdiens is. In aansluiting by Capetz is dit daarom billik om te argumenteer dat neutraliteit (of sekularisme) ' $n$ ideologiese vertrekpunt is wat grondwetskrywing en wetsformulering net so beïnvloed soos enige ander godsdiens, ideologie of filosofie.

- Neutraliteit kan dus nie godsdiensvryheid genoegsaam waarborg nie. Die owerheid moet godsdienste benader vanuit 'n paradigmagedrewe persepsie van dit wat algemeen goed is vir godsdienste. Volgens Rawls moet so 'n persepsie lei tot die 
misbruik van mag. Hy sê: "A public and workable agreement on a single and general comprehensive conception [of the good] could be maintained only by the oppressive use of power" (Rawls, 1987:4). So iets is wat inderdaad in die praktiese toepassing van hierdie opsie gebeur.

- Die bevordering van neutraliteit in die openbare sfeer kan nie anders as om die rol van godsdienste, byvoorbeeld in die onderwys, in te perk nie. Om openbare onderwys vry van godsdiens te maak, open die deur vir die propagering van die ideologie van sekulariteit met alles wat dit inhou. Onder die vaandel van neutraliteit word 'n waardestelsel (wat tog nooit neutraal kan wees nie) ontwerp wat die lewensnorme van leerlinge bepaal. Hoe kan sake soos seksuele onderrig, geskiedenisonderrig en morele opvoeding neutraal geskied? Leerlinge word in hierdie opsie ook, soos in die aktiewe staatsgodsdiensopsie, ideologies beïnvloed. Dié opsie waarborg dus nie godsdiensvryheid nie, omdat dit godsdiens in die openbare sfeer vervang met ' $n$ ideologie wat die regering van die dag na aan die hart lê. Dit is niks anders as 'n skending van die fundamentele reg van godsdiensvryheid indien 'n kind se reg om godsdiensonderrig van sy keuse in 'n staatskool te ontvang, vervang word met die ideologie van die regerende party nie. Dieselfde probleem duik op in die godsdiensbeoefening van mense in gevangenisse en militêre eenhede.

\subsection{Die aktiewe universalistiese opsie}

Met die ontwikkeling van die teologie van godsdienste word die idee gepropageer dat die goeie en die raakpunte van alle godsdienste gesoek moet word en as 'n soort universele waardesisteem aan godsdienstige mense aangebied moet word. Hierdie godsdiens word dan veral op die vlak van spiritualiteit in intergodsdienstige aanbiddingsbyeenkomste en op die vlak van die etiese uitgedruk. As opsie in die erkenning van die fundamentele reg van godsdiensvryheid, impliseer hierdie opsie dat 'n universeel aanvaarbare godsbeskouing ontwikkel word deur middel van intergodsdienstige opvoeding.

Mense moet dan verstaan dat die god wat in die grondwet genoem word, die god is van alle godsdienste en gelowe. Op skole word in sogenaamde religieuse opvoeding die aanvaarbare en toepasbare van elke godsdiens ontgin en geweef in 'n waardesisteem, wat die harte van almal streel en aanvaarbaar is vir mense van verskillende godsdienstige oortuigings. Hierdie opsie word in die grondwetlike 
denke in Indië en Namibië aangetref. Onder leiding van die voormalige minister van onderwys in Suid-Afrika, Kader Asmal, is die grondslae van hierdie opsie in Suid-Afrika ingevoer en figureer dit veral in die leerplanne vir sogenaamde lewensoriëntering as verpligte vak vir alle leerlinge. Chidester (2001:31) moedig die deelname van kinders op skool in multi-religieuse godsdiensoefening aan, want:

Through such participation, pupils can explore the diversity of religious life in South Africa, through sacred times and places, through stories and rituals, and through the different ways of imagining what it means to be human.

Hiermee verwoord hy die bedoeling van die universalistiese opsie in Suid-Afrika.

Kritiese opmerkings hieroor is die volgende:

- Om kennis op te doen van die geskiedenis en waardes van verskillende godsdienste is aanvaarbaar. Sodanige kennis kan selfs bydrae tot begrip en respek en die huidige negatiewe stereotipering van godsdienste in die plofbare godsdienskonflikte teenwerk. Maar die universalistiese godsdiensopsie gaan verder as dit. Hiermee word eintlik 'n moderne aktiewe staatsgodsdiensopsie of, in ekstreme vorm, 'n aktiewe teokratiese opsie aan die orde gestel. 'n Nuwe godsdiens word aan almal opgedwing en dieselfde kritiek wat teen die twee genoemde opsies ingebring kan word, kan ook hierteen ingebring word.

- Met so 'n opsie vervul die owerheid ook nie sy godgegewe roeping nie. Omdat 'n nuwe godsdiens op mense afgedwing word, is die potensiaal vir godsdienskonflik groot. Mense verloor hiermee die ruimte om die reg uit te oefen om in die godsdiens van hulle eie keuse onderrig te word en 'n waardesisteem, wat uit hulle eie godsdiens voortvloei, uit te bou. Die geskiedenis leer dat sodanige beperkings die potensiaal vir maatskaplike onrus inhou, en daar is geen waarborg dat die geskiedenis nie in die toepassing van hierdie opsie, herhaal sal word nie.

\subsection{Die aktiewe plurale opsie}

Hierdie opsie is die teenoorgestelde van die aktiewe neutrale opsie. Waar die aktiewe neutrale opsie uitgaan van die standpunt dat alle godsdienste uit die openbare sfeer na die private sfeer verskuif moet word, wil hierdie opsie alle godsdienste ook in die openbare sfeer laat funksioneer. Navorsing dui nie aan of hierdie opsie al volledig in 
enige grondwetlike demokrasie funksioneer nie, maar dit is geldig om te beweer dat elemente daarvan tans in Suid-Afrika sigbaar word en moontlik is (Van der Vyver, 1999:635). Meer in besonderhede gestel, kan gesê word dat hierdie opsie aan alle godsdienstige mense die geleentheid bied om die godsdiens van hulle keuse te bely, te beleef in openbare aanbidding in die openbare sfeer en uit te dra, solank niemand anders daardeur onder enige verpligtinge gestel word nie.

In sy beoordeling van die situasie in die VSA, waar die "establishment clause" en die "free exercise clause" ondersteuning bied aan die aktiewe neutrale opsie, kom Hollenbach (2003:88) tot die gevolgtrekking dat hierdie opsie gelei het tot die totale sekularisering van die samelewing en 'n afgebreek van die morele orde. Hy pleit vir meer betrokkenheid van godsdienste in die publieke sfeer, want: "[t]here are significant groups of religious believers who are in fact corporately involved in public life and who contribute to the common good in peaceful and freedom-supporting ways" (Hollenbach, 2003:88). Hoewel hy nie sy voorkeur duidelik uitspel nie, beweeg sy argumentasie ook na die aktiewe plurale opsie.

Die implikasie van die aktiewe plurale opsie in die openbare sfeer is die volgende: Openbare byeenkomste en die parlement, asook openingsgeleenthede word met gebed geopen. Hierdie gebedsgeleenthede kan op drie wyses geskied. Mense van verskille godsdienste kan afsonderlik byeenkom en elkeen kan 'n gebedsgeleentheid binne die gebruike en tradisies van daardie godsdiens hou. By skole, in die Parlement en ander openbare byeenkomste kan Christene byvoorbeeld byeenkom vir 'n Christelike aanbiddingsgeleentheid met Skriflesing, prediking en gebed binne die raamwerk van Christelike tradisies. Dieselfde reg word ook aan mense van ander godsdienstige oortuiging gebied. Agnostici word nie verplig om enige van hierdie geleenthede by te woon nie, en niemand word gedwing om deel te neem aan 'n ander godsdienstige geleentheid nie. Waar sodanige afsonderlike byeenkomste om praktiese redes nie moontlik is nie, kan 'n enkele byeenkoms gehou word waar voorgangers van die verskillende godsdienste geleentheid kry om namens elke godsdiens 'n gebed te doen. Elkeen word toegelaat om dit binne die gebruike en vereistes van sy eie godsdiens te doen en van niemand word verwag om sy gebruike in gereduseerde vorm toe te pas om moontlike aanstoot te voorkom nie. Elke godsdiens kry geleentheid om volledig op grond van 'n eie prinsipiële basis te funksioneer. Die derde moontlikheid is om aan 
elkeen die geleentheid vir 'n stilgebed te gee. Hierdie gebruike het by Kodesa begin en word tans by verskeie owerheidsgeleenthede toegepas.

Die volgende kritiese opmerkings kan hieroor gemaak word:

- Hollenbach (2003:90) verwys na Smith wat waarsku teen 'n verdere polarisasie van die samelewing wanneer hierdie opsie toegepas word. Smith sê dat godsdienste 'n "fissiparous quality" het, wat beteken dat godsdienste geneig is om grense tussen mense te trek en in-groep/uit-groep grense te definieer. Self oordeel Hollenbach (2003:92) dat hierdie gevaar net bestaan as 'n mens met godsdienstige ekstremisme te doen het.

- Die vraag kan ook met reg gevra word of dié opsie altyd prakties uitvoerbaar is. Is dit moontlik om in staatskole, gevangenisse, die polisiedienste en verdedigingseenhede geleentheid te gee om voluit op gelyke basis te funksioneer?

- Agnostici mag oordeel dat hulle "verswelg" word deur godsdienste en dat die ruimte vir nie-godsdienstigheid ontbreek.

- Verder sou kritici kon vra of hierdie opsie nie tog ook maar die element het van universalisme en uiteindelik minderheidsgodsdienste gaan benadeel nie.

\section{Konklusie}

Die vyf opsies wat hierbo bespreek is, het almal in ' $n$ mindere of meerdere mate in die verlede en in die huidige tydsgewrig gefunksioneer, hoewel die laaste opsie nog betreklik nuut in die menseregtedebat is. Dit blyk egter dat die aktiewe plurale opsie die beste opsie is, en veral in plurale gemeenskappe oorweeg kan word. Die volgende argumente kan ter ondersteuning van hierdie keuse aangevoer word.

- So 'n opsie laat reg geskied aan almal. Uit 'n Christelik-etiese hoek beredeneer, voldoen dit aan die Bybelse perspektiewe oor die realisering van die beginsels van die koninkryk van God, omdat gelowiges in staat is om hulle roeping tot getuienis van die evangelie en aktiewe betrokkenheid in die opbou van die samelewing effektief te beoefen en dieselfde reg word aan ander missionêre godsdienste gegee.

- Hierdie opsie bied ook geleentheid vir alle godsdienste om binne die ruimte van eie beginsels ongehinderd te funksioneer. Waar 
die universalistiese opsie godsdienste wil reduseer en laat ineenvloei in een universele "roereiergodsdiens", gee hierdie opsie die volle reg aan godsdienste om binne hulle eie bane te beweeg.

- Die toepassing hiervan op sekere gebiede in Suid-Afrika toon dat die opsie wel prakties uitvoerbaar is. Openbare skole kan die geleentheid bied aan kerke en ander godsdienstige instansies om deur middel van predikante of geestelikes leerplanne vir hulle eie godsdiensgroepe op te stel en die leerders te onderrig op tye en plekke wat die skole beskikbaar stel. So byvoorbeeld kan die Rooms-Katolieke kerkgemeenskap Roomse kinders volgens 'n eie leerplan onderrig, terwyl ander dieselfde doen. Onderrig moet egter voldoen aan die vereistes vir ordelike regering en moet nie die openbare orde van 'n vreedsame en verantwoordelike demokrasie ondermyn nie

- Wanneer hierdie opsie sodanig toegepas word, kan dit nie na universalisme inbeweeg nie. Universalisme dreig slegs wanneer minderhede nie die geleentheid kry om hulle eie godsdiens te beoefen en uit te dra nie.

- In dié opsie is niemand onder die verpligting om 'n bepaalde religieuse oefening of onderrig by te woon nie. Agnostici is vry om hulle van enige godsdiensbeoefening te onttrek.

- Die aktiewe funksionering van godsdienste in die openbare sfeer kan 'n groot bydra lewer tot nasiebou, omdat almal aanspraak maak op morele beginsels en norme wat vormend en opbouend vir die mense van daardie godsdienste is.

- Vir gelowiges bied hierdie opsie die beste ruimte om "liefde aan alle mense" uit te druk, omdat dit juis ruimte skep vir mense om hulle diepste emosies uit te druk binne die spiritualiteit van hulle godsdiensoortuigings. Voorts kan die owerhede dan ook rustig wees met die wete dat gelyke ruimte aan almal gegee word om te kan funksioneer.

- Ekstremisme, waarteen Hollenbach (2003:90) met 'n beroep op Smith waarsku, bly steeds 'n bedreiging, maar godsdienste self moet ekstreme en fanatiese groeperings kalmeer. Van die owerheid kan verwag word om teen hierdie groeperings op te tree wanneer hulle die wet oortree.

Die gesindheid van Christene teenoor ander godsdienste kan die beste gedien word waar ruimte geskep word vir almal om in die openbare en die privaatsfere voluit mens te wees. Om voluit mens 
te wees beteken om die spiritualiteit van jou godsdiens te koester en jou lewe te bou op die fundering wat die godsdiens bied. Hierdie ruimte gee ook die geleentheid om jou godsdiens uit te dra in getuienis en lewenspraktyk. 'n Christelike gesindheid soek vrede en nie vervolging nie; 'n eie identiteit en nie 'n identiteitlose geheel nie; vryheid en nie staatstotalitarisme nie en regte sonder kwaadwillige beperkings.

\section{Geraadpleegde bronne}

BEASLEY-MURRAY, G.R. 1987. Jesus and the kingdom of God. Grand Rapids: Eerdmans.

BLEI, K. 2002. Freedom of religion and belief: Europe's story. Assen: Van Gorcum.

BONHOEFFER, D. 1995. Ethics. London: Simon \& Schuster.

CAPETZ, P.E. 2004. The first commandment as a theological and ethical principle. (In Brown, W.P., ed. The ten commandments: the reciprocity of faithfulness. Louisville: Westminster John Knox. p. 174-192.)

CHASKALSON, G. 1997. State vs Solberg. 1997(10) BCLR 1348 (CC) Par 100.

CHIDESTER, D. 2001. Multiple voices: challenges posed for religious education in South Africa. (In International Association of Religious Freedom. Religious education in schools: ideas and experiences from around the world. Oxford: International Association of Religious Freedom. p. 26-31.)

CONZELMANN, H. 1976. An outline of the theology of the Old Testament. London: SCM.

DE VAUX R. 1988. Ancient Israel: Its life and institutions. London: Darton, Longman \& Todd.

DOUMA, J. 1996. The ten commandments: manual for Christian life. Phillipsburg: P \& R Publishing.

DU TOIT, S. 1969. Die koninkryk van God in die Ou Testament. (In Du Toit, S., et al. Die koninkryk van God. Potchefstroom: Pro Rege. p. 11-33.)

FEDLER, K.D. 2006. Exploring Christian ethics, Biblical foundations for morality. Louisville: Westminster John Knox.

GER

kyk Gereformeerde Ekumeniese Raad

GEREFORMEERDE EKUMENIESE RAAD. 1983. RES testimony on human rights. Grand Rapids: Reformed Ecumenical Council.

GOVERNMENT OF FRANCE. 2004. Luin 2004-228 du Mars 2004.

GREEN, V. 1998. A new history of Christianity. Gloucester: Sutton.

HASHMI, S. 2006. Cultivating a liberal Islamic ethos, building an Islamic civil society. Voordrag gelewer by die Society of Christian Ethics, Phoenix, Arizona, 6 Januarie 2006.

HELBERG, J.L. 1980. Die Here regeer, openbaringslyne deur die Ou Testament. Pretoria: N.G. Kerkboekhandel.

HOLLENBACH, D. 2003. The common good and Christian ethics. Cambridge: Cambridge University Press.

KAO, G.Y. 2006. "One Nation under God", or, Taking the Lord's Name in vain? Christian reflections on the Pledge of Allegiance. Voordrag gelewer by die Society of Christian Ethics, Phoenix, Arizona, 6 Januarie 2006. 
KUHN, T.S. 1970. The structure of scientific revolutions. Chicago: The University of Chicago Press.

KÜNG, H. 1992. The church. Kent: Burns \& Oates.

RAWLS, J. 1987. The idea of overlapping concensus. Oxford Journal of Legal Studies, 1987(7):1-25.

RAWLS, J. 2001. Collected papers. London: Harvard University Press.

SCHMIDT, K.L. 1969. Basileia. (In Kittel, G., ed. Theological Dictionary of the New Testament. Grand Rapids: Eerdmans. p. 579-593.)

TIERNEY, B. 1996. Religious rights: a historical perspective. (In Reynolds, N.B. \& Durham, W.C. Religious liberty in Western thought. Atlanta: Scholars Press. p. 29-57.)

VAN DER VYVER, J.D. 1999. Constitutional perspective of church-state relations in South Africa. Brigham Young University Law Review, (2):635672.

VAN DER WALT, T. 1962. Die koninkryk van God - naby! Kampen: Kok.

VERENIGDE NASIES. 2004. Civil and political rights, including the question of religious intolerance. Report submitted by Asma Jahangir, special rapporteur of freedom of religion or belief. Geneva: United Nations. Document E/CN.4/2005/61. 20 December 2004.

$\mathrm{VN}$

kyk Verenigde Nasies

VORSTER, J.M. 1993. Godsdiensvryheid in die lig van artikel 36 van die Nederlandse Geloofsbelydenis. In die Skriflig, 27(3):307-321.

VORSTER, J.M. 1994. Tendense in die teologie van die Wêreldraad van Kerke sedert 1948. Studia Historiae Ecclesiasticae, 20(2):234-253.

VORSTER, J.M. 2004. Ethical perspectives on human rights. Potchefstroom: Potchefstroomse Teologiese Publikasies.

VRIEZEN, T.C. 1966. Hoofdlijnen der theologie van het Oude Testament. Wageningen: Veenman.

WALKER, W. 1992. A history of the Christian church. Edinburgh: Clark.

WARNINK, H. 2005. Religious freedom: current issues in Belgium. Voordrag gelewer by die konferensie oor die kerk/staat verhouding in Suid-Afrika op 27 Oktober 2005 te Stellenbosch. (Kopie in besit van outeur.)

WITTE, J. 1996. Moderate religious liberty in the theology of John Calvin. (In Reynolds, N.B. \& Durham, W.C. Religious liberty in Western thought. Atlanta: Scholars Press. p. 83-122.)

\section{Kernbegrippe:}

Christelike gesindheid

godsdiensregte

godsdiensvryheid

staat en godsdiens

teokrasie 


\section{Key concepts:}

Christian attitude religious freedom religious rights state and religion theocracy 